This is a post-print accepted manuscript published in

Hospitality \& Society

Please cite this publication as follows:

Ikonen, Hanna-M ari (2017). Passionately yours: M anaging emotional and spatial boundaries in lifestylebased hospitality businesses. Hospitality \& Society 7:3, pp. 263-280. DOI:

https://doi.org/10.1386/hosp.7.3.263_1

\title{
Passionately yours: Managing emotional and spatial boundaries in lifestyle-based hospitality businesses
}

Author: Hanna-M ari Ikonen, University of Tampere

\section{Abstract}

This article examines the boundary work done by self-employed men and women in rural areas, whose goal is to accomplish their lifestyle aspirations. Their business model is to host people, specifically dog owners, at their homes, offering a space to spend some leisure time and train in dog sports in a rural setting. For the host-entrepreneurs, the work is also their lifestyle and, therefore, the conventional boundaries between professional and personal life are constantly blurred. The article suggests that the emotionally demanding work of crossing the boundaries between private and public is motivated by their passion for their lifestyle-a desired attribute in the new economy. Although they appear to be ideal workers as per the rules of the new economy, the business and lifestyle depend on their infinite passion.

Keywords: work-life balance, lifestyle entrepreneurship, hospitality, new economy, passion, dogs

\section{Introduction}

Being passionate about one's work is usually seen in a positive light. As a term, 'passion' is defined as the strong inclination towards an activity that one likes, finds important and in which one invests time and energy (Vallerand and Houlfort 2003: 175). In the spirit of the new economy - which refers to the transition towards a service-based, immaterial, affective and knowledge economy and the fusion of production, reproduction and consumption (Adkins 2005; 2016; M cDowell and Dyson 2011) - an entrepreneurial mindset is expected, and economic activity can be generated from various attributes (Luckman 2016; Ikonen 2016). Feeling and expressing passion towards what one does is an ideal expected from workers in the new economy to be employable and successful at work, and yet being passionate is not a new thing as such. When working with passion, the boundaries between work and non-work, as we know them from the Fordist era, blur (Umney and Kretsos 2015). However, on a day-to-day basis, different kinds of efforts are made to establish boundaries.

This article empirically looks at lifestyle entrepreneurship motivated by personal passion and researches the related boundary crossings and actions taken to maintain boundaries undertaken by home-based entrepreneurs running dog-related rural hospitality businesses. The six case studies used as examples of the contours of the new economy are of self-employed people who operate in the Finnish or Swedish countryside and offer accommodation particularly for dog hobbyists or coaching in dog sports i.e. they train people in improving their performance in dog activities, which is also their hobby. Another motivation for 
the entrepreneurs to change their lifestyles has been past experience with work-related inconveniences in their previous working life.

The article focuses on the balancing work that is performed between boundaries of work and what used to be a hobby; of the private home and public areas and of emotions that can be publicly displayed or experienced in private. The main question is how the entrepreneurs' passion - for dogs, dog sports, the rural life, 'doing their own thing', 'having it all' and their consequent lifestyle entrepreneurship in the hospitality sector - is related to the necessity (or lack, thereof) of work-life boundaries in the context of the new economy. Passion is defined here as an affect the entrepreneur genuinely feels and is also what makes them potentially successful as per the rules of the new economy. This affect - passion - becomes the starting point to initiate economic activity, but passion as a prerequisite for lifestyle entrepreneurship may also be a risk.

The article contributes to existing research on hospitality by examining the contribution of scholarly discussions on the new economy and its style of work - flexible, enterprising, affective and precarious - as this might help in understanding hospitality work. The article also makes a contribution by placing at its centre theories around work-life boundaries and examining them in the context of hospitality work and the new economy, in which clearly demarcated boundaries are arguably difficult to establish. As an empirical contribution, a new niche business in hospitality sector is introduced. As a result, the concept of passion is suggested to be a uniting element in hospitality work, which fundamentally involves working with emotions, and in the ultimate spirit of the new work. After all, however, it depends on the chosen perspective whether passion is anything new in hospitality work. On the one hand, blurring boundaries and strongly liking one's work is what small-scale hospitality business has always been and what hospitality researchers have shown. On the other hand, the phenomenon of turning a particular passion into an enterprise and the reasons for doing so bear elements of the changes that theorists of the new economy have previously discussed, making this examination of passion relevant specifically to hospitality research.

\section{Work- life boundaries in 'old' and 'new' work}

When hospitality becomes a lifestyle-based business, the separation of personal and professional life becomes unclear or even unwanted. Generally, boundaries between work and non-work can be considered an issue of work-life balance. The literature on work-life balance is extensive, and it essentially though not always explicitly deals with boundaries between the different domains of life. The implicit assumption is that a boundary is required. To contextualize this, I roughly place studies on work-life boundaries into four broad categories: those addressing work done outside the home; those addressing work done mainly from home for an outside employer, such as telecommuters; work done at home mainly through self-

employment and, as in the cases studied here, work done at home with customers visiting that home.

Scholars have typically been interested in boundaries between work and home/ family/leisure when working outside the home. Employees working outside the home are able to separate the spheres of work and private life (e.g. Ashforth, Kreiner and Fugate 2000; Campbell Clark 2000; Nippert-Eng 1996), but what this means in practice varies according to the type of job (e.g. academics in case of Ylijoki 2013, other professionals in case of M oen, Lam, Ammons and Kelly 2013 and hairstylists in case of Cohen 2008, 2010). Considerably more attention has been paid to work-family balance than work versus other life domains (e.g. Närvi 2012, Salmi \& Lammi-Taskula 2014, Halford 2006). This is despite the fact that the one-sided nature of the work-life discussion, in which the opposite of work is always the family and not any other duties or passions, has been rightfully criticized (Ransome 2008; Warhurst, Eikhof and Haunschild 2008). 
In addition to the spatially separated domains of work and life, boundaries are also dealt with when working from home. The places where people work are changing (Felstead, Jewson and Walters 2005), and telecommuting for an employer from a home office is a typical example of this. There is a large body of literature on the potential and problems of doing waged work partly from home and partly at the employer's premises (Kylin \& Karlsson 2008). The studies say, for example, that both male and female professionals who telecommute experience positive integration and stress (M irchandani 2000), while women specifically experience conflicting emotions because of the blurred boundaries between the spaces of leisure and work (Dart 2006).

A slightly different situation that is marked by issues of work- leisure boundaries is when a person works at home, that is, s/he does not commute to a workplace outside the home at all. M ost often, this means working as a small-scale entrepreneur. A person may be contracting for a bigger enterprise or working on their own business at home. M any freelancers, craftspeople selling their crafts on the web, graphic designers and other types of creative workers are good examples of this type of work (Conor, Gill and Taylor 2015; Luckman 2015; Taylor 2015; Vorley and Rodgers 2014). Also, new forms of working from home - or from cafes, buses or any other location where a mobile device can be used - emerge, as do new conceptions of what is actually considered work (e.g. blogging, posting videos to YouTube and other income-generating activities conducted on social media platforms).

Finally, boundaries may cause particular confusion when working at home with customers who come there, as is the case in this study. Hosting businesses are generally good examples of this acute emotional dilemma regarding what is private and what is public (Brandth and Haugen 2012; Cederholm 2015; Cederholm and Hultman 2010; Cederholm \& Åkerström 2016; Di Domenico and Lynch 2007; Lashley and M orrison 2003). Such work makes several boundaries more apparent. Hosts are at work while visitors have leisure time; hosts are working at home, so they no longer have a place to rest in the most typical sense and as they are in a home, visitors expect personal service, a fact that adds yet another emotionally complicated facet to the issue of spatial and temporal blurring of consumption, production and reproduction. Fundamentally, home is exclusively private, non-commercial and non-work related (Douglas 1991), but in the new economy, this boundary and its resultant feeling of privacy is severely broken as work spills out beyond a literal working time and place, sometimes voluntarily and passionately and sometimes less so. In the passion-motivated hosting business, it is not only the home that becomes commercialized, public and occupied but also the entrepreneur's lifestyle. Even when a certain lifestyle is desirable, it may lead to tensions. This is why the combination of boundary work and passion is worth scrutinising.

\section{The new economy and the hospitality business: Working with the innermost self}

It is fundamental to small-scale hospitality businesses that the entrepreneur's self is totally involved with the work. This is also what is expected from workers in the new economy: to exhibit excessive attachment to work through their bodies, minds and psychic lives (Ikonen 2013; Irving 2016). In hospitality work, the self is opened to the public, although not completely, and it is here that the need for boundaries is considered. Hosts and coaches who work at home or coaches, who are the focus of this study, are in a way always on stage. Compared with Goffman's (1956/1990) ideas about backstage and forestage, hosts in the new economy can hide backstage only partly. All of their skills and characteristics are exposed and open to customer evaluation during the entirety of their visit and even before and after the visit, as customers make their decisions - most often by browsing the Internet to learn about others experiences - and later evaluating the visit. Even the physical space is continuously under evaluation. While the whole idea is that visitors come to their place, it has to be negotiated how, how much and when the home, which is basically a private space, is open and public. Because a home is a strongly emotional place, emotional labour is 
needed to open it up to visitors. Efforts are needed to keep a commercial home intimate, without any emotional or aesthetic displays (M clntosh and Harris 2009).

The hospitality business is service work by its very nature and has been studied as such. The need to control emotional displays to produce the right states of mind in customers, which is the basic assumption in the emotional labour debate (Hochschild 1983; Guerrier and Adib 2003), and the need to reflect on the aesthetics of the self and the enterprise environment (Hancock and Tyler 2007; Witz, Warhurst and Nickson 2003), which is highlighted in the aesthetic labour discussion, are foundational to this business. To a great degree, what they do is embodied labour in which one's work is to a great extent based on one's self: people are always performing with their bodies and personalities. However, entrepreneurs in the service sector open themselves up more pervasively than wageworkers. Working as a rural host or coach is to run a business in which the product the customer gets is the experience, and this experience is closely intertwined with the person providing it (Brandth and Haugen 2012; Cederholm and Hultman 2010; Lynch 2005). The paying customer most probably gets the best experience if the host or coach is passionate about the basic idea s/ he offers as an experience. Therefore, performing the work requires intrinsic, constant and an all-pervading personal commitment. And, therefore, the practice of commercialized passions is worth scrutinising.

\section{Research data: Reconceptualising a passion for business}

The data for this research consists of interviews and participatory observations of six case businesses. Together, the respondents include twelve people, some of whom work alone and others who work with partners. Three of the firms provide coaching in dog sports (one of which also offers accommodation), and the other three provide premises for dog sports, including accommodation and training areas (one of these firms also offers some training; all three also serve target groups other than dog hobbyists). All the entrepreneurs have dogs as a hobby. Some were passionate and successful competitors in dog sports who wanted to make their hobby into an income-generating lifestyle. Others had started their businesses in response to seeing a niche market for providing accommodation and training premises for other dog hobbyists, which emerged from their own experience of owning and travelling with their dogs and developing a passion for rural life. This led them to realize that they could combine their passion for dogs with their desire for an autonomous work and family. In case of both types of passions (for a specific dog sport or the general desire for 'having it all' and 'doing their own thing'), living according to passion meant a radical change in their lifestyle and efforts to balance the boundaries between work and life in a different way than in their previous jobs.

The entrepreneurs now work at home. In one case (see Accommodation 3 in Table 1), the entrepreneurs live part-time in their old homes, but the business place modified into a site of commercial activities has become emotionally significant through this transformational labour. None of them are farm diversifiers and do not have previous connections to the places in which they run their businesses. Instead, they moved to rural areas to set up the business. Indeed, appropriate spaces are mostly likely to be found in rural areas where there is enough space and enough fields, forests and buildings appropriate for training, accommodation and catering services. The places are close enough to urban areas where most of their customers reside but not so close as to make land prices unaffordable. Additional information showing, for example, the business owners' family and income situations, is presented in Table 1. 
Table 1. Basic information about the case enterprises

\begin{tabular}{|c|c|c|c|c|c|}
\hline Business & $\begin{array}{l}\text { Entrepreneur(s) } \\
\text { and family } \\
\text { situation }\end{array}$ & $\begin{array}{l}\text { Previous } \\
\text { work }\end{array}$ & Location & $\begin{array}{l}\text { Age of } \\
\text { business }\end{array}$ & $\begin{array}{l}\text { Other sources of } \\
\text { income }\end{array}$ \\
\hline Coaching 1 & $\begin{array}{l}\text { Woman, } 30 \text {, } \\
\text { married, a small } \\
\text { child }\end{array}$ & $\begin{array}{l}\text { Banking } \\
\text { sector }\end{array}$ & $\begin{array}{l}\text { Southwest } \\
\text { Finland }\end{array}$ & $\begin{array}{l}\text { A couple of } \\
\text { years }\end{array}$ & $\begin{array}{l}\text { Wage work, } \\
\text { which they will } \\
\text { probably also } \\
\text { continue in the } \\
\text { future }\end{array}$ \\
\hline Coaching 2 & $\begin{array}{l}\text { Woman, } 30+\text { in a } \\
\text { relationship, } \\
\text { collaborating with } \\
\text { another firm run } \\
\text { by a couple, } 60+\end{array}$ & $\begin{array}{l}\text { Student of } \\
\text { natural } \\
\text { sciences \& } \\
\text { Farmers }\end{array}$ & $\begin{array}{l}\text { Southern } \\
\text { Sweden }\end{array}$ & $\begin{array}{l}\text { Approximately } \\
\text { ten years }\end{array}$ & No \\
\hline Coaching 3 & Couple, $40+$ & $\begin{array}{l}\text { Trade } \\
\text { sector }\end{array}$ & $\begin{array}{l}\text { Southwest } \\
\text { Finland }\end{array}$ & A few years & Another firm \\
\hline Accommodation 1 & $\begin{array}{l}\text { Couple, } 30+\text {, small } \\
\text { children }\end{array}$ & $\begin{array}{l}\text { Education } \\
\& \\
\text { economics }\end{array}$ & $\begin{array}{l}\text { Southwest } \\
\text { Finland }\end{array}$ & A few years & No \\
\hline Accommodation 2 & $\begin{array}{l}\text { Couple, } 50+ \\
\text { teenage children }\end{array}$ & $\begin{array}{l}\text { Medicine \& } \\
\text { engineering }\end{array}$ & $\begin{array}{l}\text { Eastern } \\
\text { Finland }\end{array}$ & A few years & $\begin{array}{l}\text { Wage work, } \\
\text { which will likely } \\
\text { continue in the } \\
\text { future }\end{array}$ \\
\hline Accommodation 3 & $\begin{array}{l}\text { Woman, } 30+, \\
\text { divorced, a school- } \\
\text { aged child, \& } \\
\text { Woman, } 30+\text {, in a } \\
\text { relationship }\end{array}$ & $\begin{array}{l}\text { Several, } \\
\text { mainly the } \\
\text { trade } \\
\text { sector }\end{array}$ & $\begin{array}{l}\text { Southwest } \\
\text { Finland }\end{array}$ & $\begin{array}{l}\text { A couple of } \\
\text { years }\end{array}$ & $\begin{array}{l}\text { Wage work, } \\
\text { which they } \\
\text { would prefer to } \\
\text { discontinue in } \\
\text { the future }\end{array}$ \\
\hline
\end{tabular}

Putting the cases into a social context, their activities can be seen as lifestyle entrepreneurship in which the desired way of living, often in a much-loved place, is a central element of the business activity (Ateljevic and Doorne 2000; Cederholm 2015; Hall and Rusher 2004). For those who have children, the rationale of bringing up a family in a rural setting (Ní Liaore and Stockdale 2016) is one of the core foundational values and motivations of the business idea. The starting point is that the entrepreneurs' personal values are similar to the visitors' values, which are consequently translated into economic value (Cederholm and Hultman 2010: 17). Economic value and business growth are not the primary aims for either the men or for the women (cf. Loscocco and Bird 2012), yet the interviewees who participated in this study all emphasized their ability to understand economic realities. The rejection of an overtly profit-driven orientation towards business does not result in developmental stagnation but rather provides opportunities to engage with niche markets and attract customers who share the same interests as the host (Ateljevic and Doorne 2000). These cases are apt expressions of the experience economy, passion economy or other such terms used to describe the new economy, in which specialized and ideally passionate knowledge is transformed into profit-making activities. They are also communicated to potential customers largely via the Internet, particularly social media (also, Luckman 2015). Characteristic to the new economy, a blurring of work-life boundaries has been a given in these businesses from the very beginning.

The firms studied operate in the field of human-non-human interactions, which is increasingly drawing the interest and attention of academics (for a review, see Schuurman 2014). There is also increasing interest in the role of embodied communication between humans and animals and the material and performative 
dimensions of human-animal relationships (Ikonen \& Pehkonen forthcoming). Humans and dogs meet as companion species (Haraway 2008). The hosts and coaches share and respect the conception of humans and dogs as companions who are trying to develop a mutual understanding. Such respect cannot be taken for granted in a society alienated from nature, nor can it be taken for granted in rural tourism, where the role of animals sometimes is to exist for the use of human beings.

Coaching in this study means that a person has moved to a suitable place where $s /$ he trains people and their dogs in dog agility or sheepherding. One of the coaches also travels to other places to coach, often even abroad. The other entrepreneurs operate as accommodation hosts and may also invite coaches and attract people to participate in their training seminars on dog agility, obedience, tracking or searching, which takes place at the host's premises. Alternatively, their guests may invite a coach to the host's premises, where the guests then train, eat and entertain themselves. In addition, the accommodation becomes a place to host people who can meet other dog enthusiasts who may, for example, have a dog of the same breed, or who are travelling with their dogs and in need of a dog-friendly place to stay. Accommodation hosts also offer food and lodging to lone guests or visiting groups, as long as they accept that there are or have been dogs on the premises. All these accommodation hosts explicitly target people who travel with their dogs through special advertisements and do not just merely allow dogs on their premises. All the cases were found through various dog-related Internet forums, Facebook groups and interpersonal conversations-platforms through which dog enthusiasts regular communicate and seek appropriate meeting places and coaches.

\section{Method of 'reflexive chilling' and content analysis}

The research interviews were loosely structured in-depth interviews, focusing on themes such as the interviewees' work history, their work with their customers and other daily and seasonal entrepreneurship practices, their relation to the place of business, their family situation and their future plans. The interviews lasted from one hour to nearly three hours and were recorded and later transcribed.

The visits to the case businesses lasted from half a day to three days. In addition to merely observing, I also participated in the activities, for example, I had lunch with some of the other guests and interacted with them during training sessions, and I also spent a weekend training and enjoying the bed and breakfast services along with a couple of friends and our respective dogs. During and after the visits, I took notes about what I observed, and I also talked with the entrepreneurs outside of the actual recorded interviews (for more on conducting participant observation, see Atkinson and Coffey 2002; Atkinson and Hammersley 1994). In my research notes, I have written - and I can still recall the feeling - that because I was not there in the clear-cut role of a visitor, I sometimes felt unsure and uncomfortable during in between times when nothing special was going on. Conversely, the visitors seemed to treat me as if I were invisible, which was good as it implied that they were not changing their behaviours on account of my presence.

M y observation method could be described as 'reflexive chilling', as I observed the practices before, during and after customer encounters, informally asked the guests about their experiences and walked around scrutinising the premises. However, I did not enter the spaces where I was not explicitly told I could go. The hosts naturally knew that I was there as a researcher and my visits were agreed upon in advance. Regarding the customers, most often the main organizer of a group visit was informed of my presence and role beforehand, and s/he in turn informed the other guests in the group. Alternatively, this contact person, the hosts or I informed the others of my presence at the beginning of their visit. It is possible that there were visitors who did not receive this information, especially some sporadic visitors. However, I did not ask those guests any questions, and their behaviours were not used in my analysis. 
The analysis method used was qualitative content analysis (Hsieh and Shannon 2005; Mayring 2000). The analysis was partly theoretically or deductively (M ayring 2000) informed, as the ideas about boundaries between work and life and the changes they are undergoing in the new economy were derived from the literature (Hsieh and Shannon 2005). Accordingly, information about boundary work was sought from the interview data. Additionally, and significantly, the analysis was inductively grounded (Mayring 2000) and directly derived from the interview transcripts (Hsieh and Shannon 2005). The positive emotions towards self-chosen boundary-less work were a finding derived from the data. The actual mental and physical techniques for separating work and life domains were pulled from the empirical data, although some were also supported by the research literature. Finally, it was an empirically grounded finding that all such work was fuelled by personal passion (which, however, is difficult to prove through a single excerpt from an interview). The interview transcripts were coded according to both deductively and inductively informed themes, but in the final interpretations, both theories and empirical findings were used.

\section{The dream of self-established boundaries}

The entrepreneurs had lifestyle-driven intentions behind their decisions to move to rural areas (also, Ateljevic and Doorne 2000; Cederholm and Hultman 2010; Cederholm and Åkerström 2016; Hall 2009). This background makes them different from those actors who commercialize their inherited rural homes by providing rural idyll and traditions. These people had struggled with feelings of insecurity, unemployment, stress or exhaustion, often reported in late-capitalist working life. As a solution, they made an individual decision to start an enterprise, an idealized decision in late-capitalism as well. The labour market in times of late capitalism and the global financial crisis has made more and more seemingly affluent people change their attitudes towards work. For instance, in a study by Gorman-M urray (2011), professional middle-class heterosexual men were seen to have reformulated their spatial-emotional belonging due to the global financial crisis. They invested less in work as a site of self-worth and increased their attachments to home to better their individual sense of well-being. In a similar vein, these case studies are illustrations of individualized work trajectories. All of the interviewed entrepreneurs had something negative to say about late-capitalist working life: cooperation negotiations preparing for redundancies at work, the intense pace of work, work stress, difficulties in finding a job, conflicting expectations and lack of support and praise from management. As an attempt to find a solution, they wanted to 'do something else with their life' and dedicate themselves to activities they felt would be their 'own thing'. Importantly, as entrepreneurs, they also felt that they could improve their work performance and personal working life in general, as seen in the following interview excerpt:

Now that we have an enterprise, we get to use all the proper tools that it is possible to get. And they are exactly like we want them to be. And we get to hear all the feedback, whether it is critical or good, and we can just react to it directly. As entrepreneurs we can decide. (Accommodation 3)

This is more like a way of living. This doesn't feel like work, well I'm not paid, but I don't have working hours, either. However, I have very little free time. I don't have vacations. But on the other hand, I can just do nothing if I feel like it.

(Coaching 3) 
They manage the boundaries within work as well as between work and life by themselves, and this is the lifestyle they had dreamed about. However, in hospitality businesses, these boundaries can be selfestablished only to a certain degree. Customers continue to make claims to their services, and because they often share their customers' passion for dogs, the entrepreneurs' work-life boundaries become porous. It is exactly this deep involvement in their work with dogs and doing 'their own thing' in a rural environment that regulates their work in the direction of boundarylessness.

\section{Not drawing boundaries}

As stated earlier, the work of these hosts and coaches who work at home is often based on their entire selves. Therefore, boundaries are not always drawn. The blurring of boundaries is not problematic in and of itself but is related to an individual's own conception of work (Fangel and Ballegaard 2008). Cohen (2008: 132) points out that ' $[w]$ ]ork relations affect both whether and how work- life boundaries are drawn, because they affect the rationales for drawing boundaries.' Among the self-employed people studied here, one rationale for not drawing clear boundaries was the original desire to combine work, home and/or hobby. The logic was, since it was not possible to separate life domains in their previous work, why not combine them in a way that is more within their own control?

Consequently, these entrepreneurs gave up the work-leisure division known to traditional waged workers, although this separation is becoming less common even for waged employees, as we are transitioning into a society that is always 'switched on'. The interview excerpt below is a reflection on work without boundaries between public and private and between work and life boundaries. It describes how boundarylessness in a family with young children is a good thing in the big picture, but does give rise to particular challenges on a day-to-day basis.

Of course it is a challenge that work and home are the same. I mean, when we have events that go on late into the night, we have to take the kids with us. So we've come to the conclusion that it's best to take them elsewhere [...]. To their grandparents', yes. But on the other side of the coin, if you think about how many tasks you can do with the kids around, you realize how much more time you can spend together with them when work and home are in the same place [...]. I think if we had this kind of a place and no kids, we would kill ourselves in just a few years by working too hard. So in that way, the kids balance this out for us quite well.

(Accommodation 1)

Hence, the children serve as actors who set boundaries and force the entrepreneurs to create times and spaces of privacy, even though the parents would often like to continue working. For the father quoted above, there also is a conscious desire to commit to being an equal parent (for a discussion on this, see Halford 2006; Salmi and Lammi-Taskula 2014). Interestingly, although the home-based hospitality business follows the rather traditional division of tasks between genders when it is primarily marketed as a rural idyll (Brandth and Haugen 2014), according to the data collected as part of this study, such work in fact redefines traditional gendered practices. Perhaps due to their passion-fuelled lifestyle aspirations - the adopted attitude towards hosting that is prioritized over other roles and duties or the very special niche market that they serve - the small but diverse sample of entrepreneurs studied here regularly overcome gendered boundaries in their everyday practices. For example, in all three cases in which a couple was 
running a business, the male partner was involved more or as much as the female in the preparation of meals.

The research literature reminds us that customers are not friends (Brandth and Haugen 2012; Cederholm and Hultman 2010; Cohen 2010; Lashley and M orrison 2003). All visitors have to be treated kindly, which means that emotional displays have to be regulated, but real feelings of friendship should be avoided. This is a challenging part of mental boundary setting for the entrepreneurs in this study, because intimacy is seen as both a motivation for and requirement of lifestyle entrepreneurship (Cederholm and Hultman 2010). Sharing their skills in dog training, providing comfortable and quality premises for customers to train and their overall way of living, that is, their passion, is the part of their work that is most beloved to them. Additionally, some of the customers indeed are old friends or have become quite close through their shared passion and frequent visits. M oreover, in these case studies, if not friendship, good relations with visitors are of crucial importance for business promotion, because informal discussions can lead to new modes of cooperation and new customers. Word of mouth is important, because resources for formal marketing are limited, as seen in this interview excerpt: 'He [one of the first customers] had hinted on a discussion forum that our place is worth taking a look at. I didn't know he wrote that and hadn't asked him to do that' (Accommodation 1). What is more, many customers know each other, and because the market is growing, new visitors can be attracted but also lost, as seen in this interview excerpt: 'Bad news travels fast, so we're really careful [about our reputation]' (Accommodation 3). Thus, both because the entrepreneurs like to spend time with their congenial guests and because a good reputation is a prerequisite for success, customers are not distanced by the drawing of clear boundaries.

\section{Boundary-setting techniques: Protecting the hosting self on stage}

Interestingly, boundary-setting techniques are used even for work that leans towards boundarylessness. The invented techniques differ among the various coaches and hosts. In case of coaches, the techniques sometimes include adopting the position of an ordinary hobbyist or competitor, which was the source of their original passion. They participate in other coaches' training sessions or travel to trials to test their skills, rather than just organizing such events for others, as seen in this interview excerpt: 'Going to competitions is the hobby part of this activity nowadays' (Coaching 3). Hosts, on the other hand, may leave for a holiday away from home, as their homes have become places that are not solely homes: 'Because we don't need to care about the school holidays yet, we have taken time off during the winter to travel" (Accommodation 1). However, in case of both tactics, the entrepreneurs do not totally disconnect from work. In fact, they eagerly share, for example, what kinds of dogs, training methods or dog-friendly accommodation solutions they have seen during their trips.

The entrepreneurs also employed several techniques to easily switch between the two domains. The following example is of parents who need to put their children to bed in the evenings, which has to be done even when there are visitors in the house. While waiting for the children to fall asleep, the parents relax by reading magazines, because it does not help anybody to stress about unfinished duties. In the interview excerpt below, the mother consciously reflects on the meaning of this daily moment of rest:

There are nights when I'm thinking, 'Go to bed now. I still have hundreds of things to do, so please try to fall asleep now' [...]. He [the father] is better than me at relaxing in the moment. He says, 'Think about it, isn't it nice to have half an hour to read a magazine while waiting for them to fall asleep? Think of it that way.' So now, when I can't do anything else, I read a magazine!" 
(Accommodation 1)

Some boundary-setting techniques are aimed at regulating their interactions with visitors. In my field notes, I have written about the production and sharing of spatial intimacy. The entrepreneurs divide public and private spaces by having private spaces upstairs or at the other end of the house and marking these boundaries using clear signs, closed doors or slightly different styles of interiors. There is, however, a lot of variation in whether visitors are able to enter private spaces. One coach does not spend nights in the training centre, which consists of a hall and expansive outdoor areas, one room to rent with a toilet and kitchenette as well as a home-like meeting room with kitchen facilities, a TV and sofas. There, the customers are allowed to go anywhere. At another coach's place, sofas are used both by the coach and visitors; however, the division between public and private is more directly connected to time: Guests come in only for meals and for gatherings at the beginning and end of seminars. In some places, food is prepared for both the guests and hosts in the same kitchen, but in one case, the hosts made their own meals in a separate kitchen. The same types of spatial demarcations have been found in other studies on commercial homes (Brandth and Haugen 2012; Di Domenico and Lynch 2007; Hall 2009; Jennings and Stehlik 2009).

Spatial boundaries go hand in hand with temporal ones. The hosts can restrict the times when they are available for customers, even though such a boundary is hard to adhere to precisely, given that they are not working 9-5 jobs. Particularly in these businesses, the entrepreneurs' spaces and time are often publicly available when most other people are free, that is, evenings and weekends. On the other hand, weekdays give them more private time, as seen in this interview excerpt: 'Our working hours are totally different from those who work so called normal hours. I mean, we are always working on weekends, and we have some free time on weekdays' (Accommodation 1). The work is also seasonal, meaning that there are more visitors during summers, while winters allow for more private time and space: 'Low season is nice, yes. But hey c'mon, we have eight months of quiet here anyway' (Accommodation 2). Seasonality also allows the entrepreneurs to maintain a balance between showcasing their domestic environments to visitors and enjoying the benefits of privacy offered by rural living (Goulding 2009: 109). Even still, after a while, it may become stressful to have seasonally open doors if boundaries are not also set on a daily basis. For this reason, commercial home hosts with more experience than those studied here realize that their own exhaustion at the end of a season is more apparent when they do not maintain boundaries (Brandth and Haugen 2012: 190).

Protecting oneself mentally also includes attempts at limiting face-to-face communication only to positive and easy issues and presenting more complex matters such as house rules in written form. Also, making sure that the visitors know the rules beforehand ensures that negative feedback caused by uncertainty remains minimal: 'Rules are sent when they are asked to pay the reservation fee, so that nothing is unclear' (Accommodation 3). Such clarity is intended to avoid the kind of emotional labour and effort that would go into concealing inappropriate emotions (Benmore 2009). In this way, they only present, and ideally only feel, positive emotions in customer interactions.

Of course, the entrepreneurs experience emotions that cannot be publicly displayed because they do not conform to cultural expectations (for more on rules in emotional labour, see Hochschild 1983: 118-119). There are several examples of hidden anger in the research data, but the following example presents a sense of shame about being in a wrong, unexpected place and the related uncommunicativeness. The couple quoted here also serves customers apart from dog hobbyists, and it is with these other visitors that their passion is not typically discussed: 
We had a group of retired women here, it was near the beginning and I didn't quite feel at home in the kitchen. Those grannies, they oozed statements like, 'We have been cooking for 80 years'. They then praised me with, 'Oh, what delicious food you have prepared! Have you gone to cooking school?' I was very nervous, and I sputtered, 'No, no, we have only gone to university.' My husband was laughing at me in the kitchen, 'Listen to yourself now!' But it is all about who you're talking to and their assumptions. (Accommodation 1)

This example is of an innkeeper couple, one of whom is a trained high school teacher and the other a trained economist. Their educational backgrounds as well as their young ages and the fact that they both worked in the kitchen (as they still do) made them atypical rural entrepreneurs in the eyes of the visitors, as seen in the example above. Therefore, this couple sometimes chooses not to talk much about their backgrounds and reasons for their lifestyle change. They simply do the work, necessarily with a personal touch, but not so personal that they have to explain their values and choices to everyone. The boundary here is intended to smoothen communication from one situation to another, such as in Hochschild's (1983) conception of surface acting in emotional labour. Their work otherwise allows for deep acting (Hochschid 1983) and the expression of deep emotions, such as their passion for dogs and their current lifestyle. To ensure smooth interactions, they sometimes hide their own values, even those on which their whole enterprise is based. Polite interactions with hosts and coaches is important for customer satisfaction and business success, but this professional demonstration of 'niceness' is also necessary for their own mental well-being - doing and saying only what is expected is less demanding than persistently presenting and arguing for one's innermost self.

\section{Conclusions: Boundaries and passion in hospitality business in the new economy}

To summarize the findings, on the bright side, by generating income through their own passions, selfemployed hosts or coaches are, to some extent, freely able to set their own boundaries. Individuals can make a living doing what they are good at and, more importantly, what they are passionate about. They are also more able to set their own schedules than in paid employment, which makes it easier to integrate their various life domains and enjoy the spillover between them. It is also a rewarding part of hospitality work to live in a place they like and have the possibility of modifying the firm's premises - the house, home, garden, fields, halls and other buildings - so that they are functional and suited for the purposes of their unique lifestyles.

Then again, boundary issues can become problematic, both because of business competition and internal motivation, that is, passion. All of the accommodation hosts and coaches studied here seemed to have a good reputation, but they were well aware that there is a lot of competition, perhaps not so much for their exact business but in the general business of providing spaces for leisure. Especially in economically hard times, people closely evaluate where to spend their money, whether to travel, whether to choose full board and so on. This means that the hosts have to be very flexible and ready to fulfil specific requests. Consequently, work-private life boundaries cannot be strict so as not to miss out on any potential visitors. A lack of visitors would naturally lead to worries about earning a living. What is more, even though having a passion for work is a positive thing from many points of view, it may result in exhaustion. If a person does not draw work-life boundaries, their workload can become too heavy. Without a boss and workmates, there is not necessarily anybody else to notice one's need for rest and privacy, which may lead to serious problems in the entrepreneur's well-being. The relatively fledgling entrepreneurs studied here did not report such problems, and neither did I observe them, but more research is needed on boundary work in 
businesses that have been operating for a longer time (see Brandth and Haugen 2012), as even the data collected for this study had mentions 'taking a long breath' after the high season.

In the new economy, blurred boundaries between life domains are typical; it is sometimes even unclear what is work and what is the rest of life. This overlap between different spheres of life did not exist before the Industrial Revolution (Davies and Frink 2014; Di Domenico and Lynch 2007), when there was a more stable waged society with a clear demarcation between work and home. However, the current economy that banks on worker flexibility, innovativeness, entrepreneurial spirit, digital technologies and performed enthusiasm has created a different context for boundary negotiations. Because working lives are drastically changing and jobs and careers are becoming more boundaryless, the way in which work is experienced and balanced with other aspects of life has newly emerged as a critical issue. This article aimed to enhance the comprehension of work-life boundaries in this context, through the example of dog-related businesses. The origin of these businesses lay in the entrepreneurs' passion 'doing their own thing'. Following one's passion was preceded by dissatisfaction with what their previous working life offered them: too much work, that was too insecure and had too little autonomy and substance. In addition, as 'hostessing', referring to a feminine attitude of serving, flexibility and eliminating boundaries, can be seen to be the grounding principle of contemporary work (Veijola and Jokinen 2008), the innovative hosting businesses studied here offered a useful view into how individuals manage boundaries in this type of new work. The evaluation of the hospitality sector that essentially operates at the crossroads of work and leisure and of private and public is relevant for understanding the chances in the labour markets throughout various sectors.

While feeling genuine passion is useful in the new economy, its potentially negative consequences are left up to individuals to solve. The hospitality business involves opening one's home, personality and values to the public, and it is therefore very affective by nature. It requires a constant balancing act between gaining privacy and being open, public and flexible. All of this can be seen as a way of adapting to the ideals of the new economy. Success is not guaranteed, but it can be very rewarding while it lasts. Further, because the customers of these businesses face similar challenges in balancing work and life, they also choose to invest time in leisure activities they find engaging and are passionate about. Today, what is appreciated is indeed this very passion, the spirit of action and individual self-fulfilment. If an activity ceases to be fun, there is always another choice at hand. For those who have gone through the process of turning their passions into work and have invested in a new lifestyle, however, going the other way may be more complicated.

\section{References}

Adkins, L. (2005), 'The New Economy, Property and Personhood', Theory, Culture and Society, 22: 1, pp. 111-130.

Ateljevic, I. and Doorne, S. (2000), '“Staying within the fence": Lifestyle entrepreneurship in tourism', Journal of Sustainable Tourism, 8: 5, pp. 378-392.

Atkinson, P. and Coffey, A. (2002), 'Revisiting the relationship between participant observation and interviewing', in J. F. Gubrium and J. A. Holstein (eds), Handbook of Interview Research. Thousand Oaks, CA: SAGE, pp. 801-814.

Atkinson, P. and Hammersley, M. (1994), 'Ethnography and participant observation', in N. K. Denzin and Y. S. Lincoln (eds), Handbook of Qualitative Research. Thousand Oaks, CA: SAGE, pp. 248-261.

Ashforth, E., Kreiner, G. and Fugate, M. (2000), 'All in a day's work: Boundaries and micro role transitions', Academy of Management Review, 25, pp. 472-491. 
Benmore, A. (2009), 'Behaving appropriately. M anaging expectations of hosts and guests in small hotels in the UK', In P. A. Lynch, A. J. M clntosh and H. Tucker (eds), Commercial Homes in Tourism. An international Perspective. London and New York: Routledge, 115-126.

Brandth, B. and Haugen, M . (2012), 'Farm tourism and dilemmas of commercial activity in the home', Hospitality \& Society, 2: 2, pp. 179-196.

(2014), 'Embodying the rural idyll in farm tourist hosting', Scandinavian Journal of Hospitality and Tourism, 14:2, pp. 101-115.

Campbell Clark, S. C. (2000), 'Work/family border theory: A new theory of work/family balance', Human Relations, 53, pp. 747-760.

Cederholm, E. A. (2015), 'Lifestyle enterprising: the 'ambiguity work' of Swedish horse-farmers', Community, Work \& Family, 18: 3, pp. 317-333.

Cederholm, E. A. and Åkerström, M. (2016), 'With a little help from my friends: relational work in leisurerelated enterprising', The Sociological Review, 64: 4, pp. 748-765.

Cederholm, E. A. and Hultman, J. (2010), 'The value of intimacy - negotiating commercial relationships in lifestyle entrepreneurship', Scandinavian Journal of Hospitality and Tourism, 10: 1, pp. 16-32.

Cohen, R. L. (2008), 'Work relations and the multiple dimensions of the work-life boundary: Hairstyling at home', in C. Warhurst, D. R. Eikhof and A. Haunschild (eds), Work Less, Live M ore? Critical Perspectives in Work and Employment, Basingstoke: Palgrave MacM illan, pp. 115-135.

(2010), 'When it pays to be friendly: Employment relationships and emotional labour in hairstyling', The Sociological Review, 58: 2, pp. 197-218.

Conor, B., Gill, R. and Taylor, S. (2015), 'Gender and creative labour', The Sociological Review, 63, pp. 1-22.

Dart, J. (2006), 'Home-based work and leisure spaces: Settee or work-station?', Leisure Studies, 25: 3, pp. 313-328.

Davies, A. R. and Frink, B. D. (2014), 'The origins of the ideal worker: The separation of work and home in the United States from the market revolution to 1950', Work and Occupations, 41: 1, pp. 18-39.

Di Domenico, M. and Lynch, P. (2007), 'Host/guest encounters in the commercial home', Leisure Studies, 26: 3, pp. 321-338.

Douglas, M. (1991), 'The idea of a home: A kind of space', Social Research: An International Quarterly, 58: 1, pp. 287-307.

Fangel A. B. and Ballegaard, S. A. (2008), 'Getting the job done: The impact of employees' conception of work-life balance', in C. Warhurst, D. R. Eikhof and A. Haunschild (eds), Work Less, Live More? Critical Analysis of the Work-Life Boundary. Basingstoke: Palgrave MacM illan, pp. 136-152.

Felstead, A., Jewson, N. and Walters, S. (2005), Changing Places of Work, Basingstoke: Palgrave.

Goffman, E. (1956/1990), The presentation of self in everyday life, Harmondsworth: Penguin.

Gorman-M urray, A. (2011), 'Economic crises and emotional fallout: Work, home and men's senses of belonging in post-GFC Sydney', Emotion, Space and Society, 4: 4, pp. 211-220.

Goulding, P. J. (2009), 'Time to trade? Perspectives of temporality in the commercial home enterprise', in P. A. Lynch, A. J. M clntosh and H. Tucker (eds), Commercial Homes in Tourism. An International Perspective, London and New York: Routledge, pp. 102-114. 
Guerrier, Y. and Adib, A. (2003), 'Work at leisure and leisure at work: A study of the emotional labour of tour reps', Human Relations, 56: 11, pp. 1399-1417.

Halford, S. (2006), 'Collapsing the boundaries? Fatherhood, organization and home-working', Gender, Work \& Organization, 13: 4, pp. 383-402.

Hall, C. M. (2009), 'Sharing space with visitors. The servicescape of the commercial exurban home', in P. A. Lynch, A. J. M clntosh and H. Tucker (eds), Commercial Homes in Tourism. An International Perspective. London and New York: Routledge, pp. 60-72.

Hall, C. M. and Rusher, K. (2004), '"Risky lifestyles"? Entrepreneurial characteristics of the New Zealand bed and breakfast sector', in R. Thomas (ed.), Small Firms in Tourism: International Perspectives. Oxford: Elsevier, pp. 83-98.

Hancock, P. and Tyler, M. (2007), 'Un/doing gender and the aesthetics of organizational performance', Gender, Work \& Organization, 14: 6, pp. 512-533.

Haraway, D. (2008), When Species M eet. Minneapolis, M N: University of Minnesota Press.

Hsieh, H.-F. and Shannon, S. E. (2005), 'Three approaches to qualitative content analysis', Qualitative Health Research, 15: 9, pp. 1277-1288.

Hochschild, A. R. (1983), The M anaged Heart: Commercialization of Human Feeling. Berkeley, CA: University of California Press.

Ikonen, H.-M . (2013), 'Precarious work, entrepreneurial mindset and sense of place: Female strategies in insecure labour markets', Global Discourse, 3: 3-4, pp. 467-481. pp. $25 \overline{6}-26 \overline{7}$.

(2016), 'Producing rural spaces for consumption: Proper states of mind', Rural Society, 25: 3,

Ikonen, H.-M . and Pehkonen, S. (forthcoming), '"I $<3$ my high-performance dog": Love for the sport in agility coach representations in social media', Sport in Society.

Irving, D. (2016), 'Future investments: Gender transition as a socio-economic event', in L. Adkins and M. Dever (eds), The post-Fordist sexual contract. Working and living in contingency. Basingstoke: Palgrave Macmillan, pp. 31-48.

Jennings, G. and Stehlik, D. (2009), '(Re)interpreting public/private domains and 'home' sites and sights', in P. A. Lynch, A. J. M clntosh and H. Tucker (eds), Commercial Homes in Tourism. An International Perspective. London and New York: Routledge, pp. 50-59.

Kylin, C. and Karlsson, J. C. (2008), 'Re-establishing boundaries in home-based telework', in C. Warhurst, D. R. Eikhof and A. Haunschild (eds), Work Less, Live M ore? Critical Analysis of the Work-Life Boundary, Basingstoke: Palgrave MacMillan, pp. 173-190.

Lashley, C. and Morrison, A. (2003), 'Hospitality as a 'commercial friendship", The Hospitality Review, 5: 4, pp. 31-36.

Loscocco, K. and Bird, S. R. (2012), 'Gendered paths. Why women lag behind men in small business success', Work \& Occupations, 39: 2, pp. 183-219.

Luckman, S. (2015), 'Women's micro-entrepreneurial homeworking', Australian Feminist Studies, 30: 84, pp. 146-160.

(2016). 'M icro-enterprise as work-life 'magical solution"', in L. Adkins and M. Dever (eds), The Post-Fordist Sexual Contract. Working and Living in Contingency, Basingstoke: Palgrave M acmillan, pp. 91108. 
Lynch, P. A. (2005), 'The commercial home enterprise and host: A United Kingdom perspective', International Journal of Hospitality Management, 24: 4, pp. 533-553.

M ayring, P. (2000), 'Qualitative content analysis', Forum Qualitative Sozialforschung / Forum: Qualitative Social Research, 1: 2, Art. 20, http://nbn-resolving.de/urn:nbn:de:0114-fqs0002204. Accessed 25 November 2016.

M cDowell, L. and Dyson, J. (2011), 'The other side of the knowledge economy: 'Reproductive' employment and affective labours in Oxford', Environment and Planning A, 43: 9, pp. 2189-2201.

M clntosh, A. J. and Harris, C. (2009), 'The discourse of home hosting. Examining the personal experiences of commercial home hosts', in P. A. Lynch, A. J. M clntosh and H. Tucker (eds), Commercial Homes in Tourism. An International Perspective, London and New York: Routledge, pp. 89-101.

M irchandani, K. (2000), "'The best of both worlds" and "cutting my own throat": Contradictory images of home-based work', Qualitative Sociology, 23: 2, pp. 159-182.

M oen, P., Lam, J., Ammons, S. and Kelly, E. L. (2013), 'Time work by overworked professionals: Strategies in response to the stress of higher status', Work and Occupations, 40: 2, pp. 79-114.

Närvi, J. (2012), 'Negotiating care and career within institutional constraints - work insecurity and gendered ideals of parenthood in Finland', Community, Work \& Family, 15: 4, pp. 451-470.

Ní Liaore, C. and Stockdale, A. (2016), 'M igration and the life course in rural settings', in M. Shucksmith and D. L. Brown (eds), Routledge International Handbook of Rural Studies, London and New York: Routledge, pp. 36-49.

Nippert-Eng, C. (1996), 'Calendars and keys: The classification of "home" and "work"', Sociological Forum, 11: 3, pp. 563-582.

Ransome, P. (2008), 'The boundary problem in work-life balance studies: Theorising the total responsibility burden', in C. Warhurst, D. R. Eikhof and A. Haunschild (eds), Work Less, Live More? Critical Analysis of the Work-Life Boundary, Basingstoke: Palgrave MacM illan, pp. 62-79.

Salmi, M. and Lammi-Taskula, J. (2014), 'Policy goals and obstacles for fathers' parental leave in Finland', in G. B. Eydal and T. Rostgaard (eds), Fatherhood in the Nordic Welfare States. Comparing Care Policies and Practice, Bristol: Policy Press, pp. 303-324.

Schuurman, N. (2014), 'Blogging situated emotions in human-horse relationships', Emotion, Space and Society, 13: 4, pp. 1-8.

Taylor, S. (2015), 'A new mystique? Working for yourself in the neoliberal economy', The Sociological Review, 63, pp. 174-187.

Umney, C. and Kretsos, L. (2015), '“That's the experience". Passion, work precarity, and life transitions among London jazz musicians', Work and Occupations, 42: 3, pp. 313-334.

Vallerand, R. J. and Houlfort, N. (2003), 'Passion at work: Toward a new conceptualization', in D. Skarlicki, S. Gilliland and D. Steiner (eds), Research in Social Issues in M anagement, Greenwich, CT: Information Age, pp. 175-204.

Veijola, S. and Jokinen, E. (2008), 'Towards a Hostessing Society? M obile Arrangements of Gender and Labour', NORA - Nordic Journal of Feminist and Gender Research, 16: 3, pp. 166-181.

Vorley, T. and Rodgers, P. (2014), 'Home is where the business is: Incidents in everyday life and the formation of home-based businesses', International Small Business J ournal, 32: 4, pp. 428-448. 
Warhurst, C., Eikhof, D. R. and Haunschild, A. (2008), 'Out of balance or just out of bounds? Mapping the relationship between work and life', in C. Warhurst, D. R. Eikhof and A. Haunschild (eds), W ork Less, Live M ore? Critical Analysis of the Work-Life Boundary, Basingstoke: Palgrave M acM illan, pp. 1-21.

Witz, A., Warhurst, N. and Nickson, D. (2003), 'The labour of aesthetics and the aesthetics of organization', Organization, 10: 1, pp. 3-54.

Ylijoki, O.-H. (2013), 'Boundary-work between work and life on the high-speed university', Studies in Higher Education, 38: 2, pp. 242-255. 